\title{
UPOWSZECHNIANIE DZIEDZICTWA ARCHEOLOGICZNEGO REGIONU BOBOLIC: REALIZACJE I PROPOZYCJE ${ }^{1}$
}

\section{THE DISSEMINATION OF THE ARCHAEOLOGICAL HERIATEG OF THE BOBOLICE REGION: IMPLEMENTATION AND PROPOSITIONS}

\author{
Michat Pawleta \\ Instytut Archeologii, Wydział Historyczny, Uniwersytet im. Adama Mickiewicza \\ ul. Umultowska 89D, 61-614 Poznań, Poland \\ mpawleta@amu.edu.pl
}

\begin{abstract}
This paper sets out to present how the research results and knowledge of the archaeological heritage of the Bobolice Region were disseminated under the project 'Non-invasive surveying of the potential of archaeological resources in the Bobolice region, West Pomerania Province' and offers further propositions in this regard. One of the project's essential objectives was to determine how we can use information generated through non-invasive research methods for the dissemination and popularisation of the archaeological heritage resources to the general public and how to exploit them for the development of tourism in this region of Poland

This paper provides an overview of the basic principles of the dissemination of knowledge about the cultural and/or archaeological heritage. It discusses the key initiatives in the field carried out during the project. These included a seminar, a popular science conference, lessons at schools, promotional activities and publications. Among others, the project sought to specify the possibilities for a potential use of certain archaeological structures and sites, through actions aimed at their dissemination and making them available to the general public, and a possible use in the development of archaeological tourism in the region. The recommendations presented here should be seen merely as suggestions for potential activities centred on the archaeological heritage resources in the Bobolice region.
\end{abstract}

KEY WORDS: archaeological heritage, popularisation, dissemination, non-invasive methods, Bobolice

\footnotetext{
${ }^{1}$ Tekst stanowi zmodyfikowaną i rozbudowaną wersję wcześniejszego artykułu, który ukazał się w innym miejscu (zob. Pawleta 2015a).
} 


\section{WPROWADZENIE}

Celem artykułu jest przedstawienie form upowszechniania wyników badań oraz wiedzy o dziedzictwie archeologicznym regionu Bobolic, podjętych w trakcie projektu „Nieinwazyjne rozpoznanie potencjału zasobów archeologicznych rejonu Bobolic, woj. zachodniopomorskie", , jak również dalszych propozycji w tym zakresie. Inicjatywa była realizowana w latach 2014-2015 w Instytucie Prahistorii UAM w Poznaniu przez zespół interdyscyplinarny złożony z naukowców z różnych ośrodków w Polsce: Uniwersytetu im. Adama Mickiewicza w Poznaniu, Uniwersytetu im. Kardynała Stefana Wyszyńskiego w Warszawie, Politechniki Warszawskiej, Uniwersytetu Warszawskiego, Muzeum w Koszalinie, a także Muzeum Lubuskiego im. Jana Dekerta w Gorzowie Wlkp. ${ }^{3}$

Generalnie projekt dotyczył wykonania badań opartych na kompleksowym wykorzystaniu nowych technik nieinwazyjnych w archeologii (lotniczego skanowania laserowego, zobrazowań satelitarnych, zdjęć lotniczych, prospekcji geofizycznej), uzupełnionych o weryfikacyjne badania powierzchniowe, celem rozpoznania, zweryfikowania oraz inwentaryzacji stanowisk archeologicznych $\mathrm{w}$ rejonie Bobolic. Jego istotnym składnikiem było także określenie wartości danych uzyskanych za pomocą tych metod $\mathrm{w}$ działaniach na rzecz konserwacji, zarządzania i ochrony dziedzictwa archeologicznego. Integralny punkt projektu stanowiła także możliwość wykorzystania rezultatów badań w celu upowszechniania informacji na temat zasobów archeologicznych tego regionu jako podstawy do działań popularyzatorskich oraz rozwijania świadomości społecznej na temat konieczności ochrony i racjonalnego zarządzania zasobami zabytkowymi oraz wykorzystania ich potencjału turystycznego.

\section{HISTORIA BADAŃ ARCHEOLOGICZNYCH NA ZIEMI BOBOLICKIEJ}

Liczne stanowiska archeologiczne $\mathrm{w}$ rejonie Bobolic zostały odkryte jeszcze przed II wojną światową, a wiele spośród nich znanych jest dziś jedynie z zapisów

\footnotetext{
${ }^{2}$ Projekt został dofinansowany ze środków Ministra Kultury i Dziedzictwa Narodowego - program Dziedzictwo kulturowe - priorytet 5 - Ochrona zabytków archeologicznych, koordynowany przez Narodowy Instytut Dziedzictwa (nr zadania 3805/14/FPK/NID). Kierownikiem grantu był autor niniejszego artykułu.

${ }^{3}$ W skład zespołu badawczego weszli: prof. dr hab. Danuta Minta-Tworzowska, prof. UAM dr hab. Włodzimierz Rączkowski, mgr Lidia Żuk (Uniwersytet im. Adama Mickiewicza w Poznaniu), dr hab. inż. Katarzyna Osińska-Skotak, mgr Sebastian Różycki (Politechnika Warszawska), dr Rafał Zapłata (Uniwersytet Kardynała Stefana Wyszyńskiego w Warszawie), mgr Paweł Kaźmierczak (Muzeum Lubuskie im. Jana Dekerta w Gorzowie Wielkopolskim), mgr Wiesław Małkowski (Uniwersytet Warszawski), mgr Jacek Borkowski, mgr Andrzej Kuczkowski, mgr Andrzej Kasprzak (Muzeum w Koszalinie), Agnieszka Ptak (MGGP Aero, Tarnów), mgr Miłosz Pigłas, Aleksandra Rakoca.
} 
archiwalnych. Przykładowo w końcu XIX w. badacz Konrad Keilhack wspomina o odkryciu wczesnośredniowiecznego cmentarzyska kurhanowego w Ubiedrzu, składającego się z 16 kurhanów z obudową kamienną, w dniu dzisiejszym już całkowicie zniwelowanych. $Z$ miejscowości tej znany jest także skarb kultury łużyckiej - cztery brązowe siekierki znalezione w 1936 r. Z kolei w miejscowości Cybulino w końcu XIX w. przypadkowo odkryto cmentarzysko kultury pomorskiej, w obrębie którego pozyskano m.in. fragmenty stopionych brązowych paciorków i pierścieni z grobów ciałopalnych. W tej miejscowości w 1892 r. pastor Dawid Klotz odkrył cmentarzysko grobów skrzynkowych. Wydobyta z grobu urna została przez niego zdeponowana w miejscu znalezienia. Naczynie to zostało powtórnie wydobyte przez Adolfa Stubenraucha.

W okresie międzywojennym badania w rejonie Bobolic prowadził Diether von Kleist, zaś zachowane z nich materiały archiwalne znajdują się w Muzeum Narodowym w Szczecinie. Wspomina on o znalezieniu m.in. kilkunastu neolitycznych narzędzi krzemiennych oraz kilku przedmiotów wykonanych z brązu i żelaza, datowanych na pradzieje, pochodzących z terenu Żydowa. Obecnie przedmioty te uważa się za zaginione. Von Kleist wzmiankuje też o istnieniu przynajmniej czterech cmentarzysk kurhanowych w obrębie wsi Żydowo, których bliższa lokalizacja nie jest obecnie znana (von Kleist 1955, tab. 11, 12).

W dziejach zainteresowania daleką przeszłością regionu Bobolic godne odnotowania jest funkcjonowanie lokalnych stowarzyszeń działających w okresie międzywojennym, które zgodnie ze swoimi statutami gromadziły znajdowane „starożytności”. Wiele znalezisk uratowali także miejscowi nauczyciele - Karl Engler oraz Ernst Dallmann. W 1922 r. w Bobolicach powstał Związek Krajoznawstwa i Ochrony Kultury Ojczystej (Verein für Heimatschutz Und Heimatkunde), którego celem było zbieranie zabytków z ziemi bobolickiej i utworzenie muzeum regionalnego. W 1934 r. w Muzeum zorganizowano wystawę stałą, w większości składającą się z zabytków archeologicznych. Znaczną część zabytków w czasie II wojny światowej przekazano do Muzeum w Szczecinie, część z nich zaginęła (Borkowski, Kuczkowski 2013, s. 18).

W latach 60. ubiegłego stulecia na terenie 12 powiatów województwa koszalińskiego przeprowadzono badania nad wczesnośredniowiecznym osadnictwem grodowym w ramach szerszych szczegółowych studiów osadniczych na Pomorzu Środkowym. Terenowe badania weryfikacyjne zainicjowano w $1961 \mathrm{r}$. i systematycznie kontynuowano do 1969 r. przy współpracy z Wojewódzkim Konserwatorem Zabytków w Koszalinie. Badaniom tym przyświecały cele konserwatorskie, naukowe, jak i dydaktyczne. Miały one przyczynić się do uzyskania pełniejszej znajomości osadnictwa grodowego na Pomorzu, a także do sporządzenia pełnej inwentaryzacji i dokumentacji obiektów obronnych dla celów konserwatorskich (Olczak, Siuchniński 1968; Łosiński, Olczak, Siuchniński 1971). W ich rezultacie zidentyfikowano liczne, nieznane dotychczas, stanowiska archeologiczne. Na wybranych stanowi- 
skach o własnej formie terenowej przeprowadzono niewielkie badania sondażowe, jak choćby w Starem Bornem, Kurowie, Drzewianach, Górawinie czy w Głodowej (Członkowski 1969a). W efekcie pozyskiwano zabytki ruchome, głównie fragmenty ceramiki. Także w przypadku Bobolic prace badawcze koncentrowały się na dwóch (z trzech istniejących) grodziskach z okresu wczesnego średniowiecza. W 1966 r. na ich terenie przeprowadzono niewielkie badania sondażowe uzupełnione o badania powierzchniowe ich najbliższych okolic, co miało na celu rozpoznanie osadnictwa wczesnośredniowiecznego wokół tych obiektów. W przypadku grodziska zewidencjonowanego jako Bobolice (stan. 2) z wykopów sondażowych pozyskano 154 fragmenty naczyń ceramicznych, kamienną osełkę, polepę i żużle żelazne (Olczak, Siuchniński 1968, s. 46-49).

W 1966 r. przeprowadzone zostały niewielkie prace terenowo-rozpoznawcze na cmentarzysku kurhanowym w Żydowie (stan 8), datowanym na X-XI w. Przebadano wówczas cztery nasypy kurhanowe. Zarejestrowano w nich groby szkieletowe z bardzo ubogim wyposażeniem - pojedynczych noży żelaznych, brązowych okuć pochewki noża, fragmentów ceramiki (Członkowski 1969b). Obecnie teren tego cmentarzyska udostępniony jest zwiedzającym, znajdują się na nim tablice informacyjne (zob. Tota 2010).

W latach 1978-1991 okolice Bobolic zostały poddane tradycyjnym poszukiwaniom powierzchniowym w ramach programu Archeologiczne Zdjęcie Polski (AZP). Kompleksowe badania powierzchniowe prowadzili w kilku etapach koszalińscy archeolodzy - Ignacy Skrzypek oraz Henryk Janocha. Prace te pozwoliły na zarejestrowanie na podstawie występujących na powierzchni zabytków, głównie fragmentów ceramiki, bardzo wielu stanowisk archeologicznych - głównie pozostałości osad otwartych, punktów i śladów osadniczych związanych z wczesnośredniowieczną i późnośredniowieczną działalnością osadniczą, lecz także z wcześniejszych okresów, m.in. mezolitu, neolitu, epoki brązu (kultura łużycka), okresu lateńskiego i halsztackiego (kultura pomorska) czy rzymskiego (kultura wielbarska). Niemniej relikty osadnicze znane są przede wszystkim z terenów odkrytych, objętych uprawą rolną. Duże zalesienie rejonu Bobolic stanowi bowiem istotne ograniczenie dla efektywnego rozpoznania zasobów zabytkowych i skutecznej prospekcji tych terenów. Szczególnie pomocne w przypadku obszarów zalesionych jest zastosowanie innych metod prospekcji, umożliwiających lepsze rozpoznawanie zasobów archeologicznych znajdujących się w lasach.

W 2005 r. pracownicy Instytutu Archeologii Uniwersytetu im. Mikołaja Kopernika w Toruniu przeprowadzili na grodzisku Stare Borne (stan. 1) badania weryfikacyjne, stwierdzając dwie fazy budowy wału tegoż grodziska. Obiekt datowano na IX-X w. Natrafiono także na relikty drewnianej drogi dębowej prowadzącej od przejazdu bramnego do przeprawy mostowej przez przewężenie jeziora. Na podstawie badań dendrochronologicznych datę konstrukcji ustalono na połowę X w. Takie datowanie odpowiada chronologii ceramiki naczyniowej, znalezionej wcześniej 
w obrębie nawarstwień kulturowych związanych z funkcjonowaniem grodu. Jest to najstarszy tego typu obiekt odnaleziony na terenie Polski (Chudziak, Kaźmierczak, Niegowski 2011, s. 251-255). W 2006 r. przeprowadzono podwodny rekonesans wokół wyspy na jeziorze Kwiecko, natrafiając jedynie na kilkadziesiąt ułamków ceramiki pochodzących z różnych okresów chronologicznych (Chudziak, Kaźmierczak, Niegowski 2011, s. 256-258).

W latach 2014-2015 z inicjatywy Instytutu Prahistorii Uniwersytetu im. Adama Mickiewicza w Poznaniu, dzięki dofinansowaniu Ministra Kultury i Dziedzictwa Narodowego, realizowano badania w ramach naukowego projektu „Nieinwazyjne rozpoznanie potencjału zasobów archeologicznych rejonu Bobolic, woj. zachodniopomorskie". Były one prowadzone przez interdyscyplinarny zespół złożony z badaczy pochodzących z różnych ośrodków naukowych w Polsce. Projekt polegał na przeprowadzeniu badań opartych na kompleksowym wykorzystaniu nowych technik nieinwazyjnych $\mathrm{w}$ archeologii celem rozpoznania, weryfikacji oraz inwentaryzacji stanowisk archeologicznych w rejonie Bobolic. Dzięki niemu odkryto kilkadziesiąt nieznanych dotychczas stanowisk. W ramach prac wykonano tradycyjne badania powierzchniowe, teledetekcję lotniczą oraz analizę wysokorozdzielczych zobrazowań satelitarnych. Prowadzono także weryfikację obszarów leśnych, opierając się na wynikach lotniczego skanowania laserowego LiDAR. Na wybranych stanowiskach w celu zidentyfikowania anomalii w promieniowaniu elektromagnetycznym poszczególnych obiektów archeologicznych zastosowano też nieinwazyjną prospekcję geomagnetyczną (zob. Pawleta, Zapłata 2015).

\section{UPOWSZECHNIANIE DZIEDZICTWA KULTUROWEGO I/ORAZ ARCHEOLOGICZNEGO}

Dziedzictwo kulturowe to materialny i duchowy dorobek przekazywany następnym pokoleniom (Przyborowska-Klimczak 2010, s. 38-40). Jak zauważa dalej autorka, pojęcie to powinno być traktowane jako pewna ogólna koncepcja ochrony dorobku kulturalnego, która wynika ze świadomości, że należy chronić to, co obecne pokolenia otrzymały od swoich poprzedników w spadku, aby móc przekazać to swoim następcom.

Szczególnym rodzajem dziedzictwa kulturowego jest dziedzictwo archeologiczne będące nośnikiem zróżnicowanych wartości. Różne także mogą być kryteria jego wartościowania, co jest uwarunkowane zarówno tym, co z materialnego dziedzictwa zostanie zachowane oraz w jaki sposób będzie ono wykorzystywane. Jak wskazuje Zbigniew Kobyliński (2001, s. 49-50), dziedzictwo archeologiczne posiada co najmniej trzy podstawowe wartości, z których wynikają jego wartości społeczno-kulturowe oraz możliwości jego dalszego wykorzystania: (1) dziedzictwo archeologiczne to źródło wiedzy o przeszłości; (2) dziedzictwo archeologiczne stanowi 
źródło tożsamości zbiorowej, które odwołuje się do przeszłości pewnych grup społeczno-kulturowych, plemion oraz narodów; (3) dziedzictwo archeologiczne jest elementem, który wspomaga rozwój kulturalny oraz ekonomiczny współczesnych społeczeństw. $Z$ tych wartości wynikają szczególne wartości dziedzictwa archeologicznego, mianowicie: (a) wartość skojarzeniowo-symboliczna: poczucie identyfikacji grupowej, odwołania do symbolicznych znaczeń kulturowych; (b) wartość estetyczna: harmonia i piękno krajobrazu archeologicznego, piękno przedmiotów i obiektów archeologicznych, (c) wartość ekonomiczna: wykorzystanie turystyczne, kreowanie miejsc pracy, czynnik zrównoważonego rozwoju; (d) wartość informacyjna: wiedza naukowa, powszechne rozumienie przeszłości (Kobyliński 2001, s. 68-79).

Obecnie w doktrynie konserwatorskiej można zauważyć stopniowe odchodzenie od idei ochrony dziedzictwa archeologicznego na rzecz jego racjonalnego zarządzania, w myśl założeń koncepcji zrównoważonego rozwoju. $Z$ jednej strony wskazuje się, że dziedzictwo to przedmiot ochrony, $z$ drugiej natomiast potencjał, który powinien zostać zaadaptowany do nowych warunków i wykorzystany do rozwoju kulturalnego i gospodarczego. Powyższa konstatacja polegająca na poszukiwaniu w warunkach gospodarki rynkowej i postępującej globalizacji - kompromisu między ochroną dziedzictwa a rozwojem, zmusza do zmiany pasywnej filozofii ochrony dziedzictwa i konieczności przewartościowania stosunku do niego (Broński 2006, s. 12-14; Purchla 2008, 56). Skoro dziedzictwo ma służyć współczesności, której jest częścią, zauważa się konieczność wypracowania systemu jego ochrony oraz zarządzania dla współczesnych ludzi przekonującego. Koncepcja racjonalnego zarządzania dziedzictwem archeologicznym będzie więc polegać na jego wykorzystywaniu w taki sposób, aby uzyskać możliwie jak największą długoterminową korzyść dla obecnych pokoleń, ale również z zachowaniem możliwości spełniania przez nie aspiracji oraz potrzeb przyszłych pokoleń (Kobyliński 2001, s. 102-104; Carman 2005; Schofield 2008, s. 20-22; Stone, Hui 2015; Underhill, Salazar 2016). Innymi słowy zarządzanie dziedzictwem archeologicznym dotyczy podejmowania decyzji dotyczącej tego, co z jego materialnych pozostałości zostanie zachowane oraz tego, w jaki sposób będzie ono wykorzystywane obecnie oraz w przyszłości. Podkreślony zostaje tym samym ,utylitarny” charakter dziedzictwa archeologicznego, przejawiający się w różnych funkcjach, jakie może ono aktualnie odgrywać w życiu różnych grup ludzi, a także zróżnicowanie wartości, które są mu przypisywane. Ponadto dziedzictwo stanowi wspólną własność społeczeństwa, które ma prawo do korzystania z niego na różny sposób i w różnych celach (np. turystycznych), jednak tak, aby nie uszczuplało to jego zasobów i nie było zagrożeniem dla jego integralności (Jaskanis 1999, s. 25; Kobyliński 2009b, s. 123; 2010, s. 16).

Z powyższymi kwestiami nierozerwalnie połączone są zasady udostępniania i upowszechniania dziedzictwa społeczeństwu, jak również jego publicznej ekspozycji. Nie stanowi to kwestii dobrowolnego wyboru bądź chęci archeologów, lecz 
jest spoczywającym na nich obowiązkiem. Wynika to z podstawowego założenia, że dziedzictwo archeologiczne chronimy nie tyle dla specjalistów (archeologów), lecz dla społeczeństwa (np. Sullivan, Mackay 2012). Każda forma naukowej działalności archeologów ma bowiem charakter publiczny, ponieważ dotyczy dziedzictwa, które stanowi własność publiczną oraz jest finansowana ze środków publicznych (McGimsey 1972; Kobyliński 2009b, s. 121). Jednocześnie towarzyszą temu zasady publicznej odpowiedzialności za dziedzictwo archeologiczne oraz publicznej kontroli sposobów korzystania z niego. Oznacza to, że społeczeństwo ma prawo być informowane na jego temat w sposób jasny i zrozumiały, jednocześnie zaś oparty na naukowych podstawach, ma prawo korzystać z jego wartości w sposób nieniszczący oraz ma obowiązek je chronić (Kobyliński 2009a).

Zagadnienie upowszechniania i popularyzacji dziedzictwa kulturowego, w tym archeologicznego, wiąże się z postulatem kształtowania społecznej świadomości ochrony dóbr kultury. Zapis takiej treści znajduje się m.in. w Konstytucji Rzeczypospolitej Polskiej z 1997 r., której art. 6 ust. 1 wyraźnie wskazuje, że państwo polskie jest nie tylko uprawnione, lecz wręcz zobowiązane do stwarzania warunków do upowszechniania dóbr kulturowych i wiedzy o zabytkach, jak również do równego dostępu do dóbr kultury będących źródłem tożsamości narodu polskiego, jego trwania oraz rozwoju. Upowszechnianie wiedzy o zabytkach - co wynika z obowiązujących przepisów ustawy z dnia 23 lipca 2003 r. o ochronie zabytków i opiece nad zabytkami (Dz.U. z 2014 r. Nr 5, poz. 1446) - jest również jednym z zadań wojewódzkich konserwatorów zabytków (art. 91, ust. 4, pkt 8). Z kolei „Europejska konwencja o ochronie dziedzictwa archeologicznego" (tzw. Konwencja Maltańska) z 1992 r., ratyfikowana w 1996 r., zobowiązała Polskę, aby „promować publiczny dostęp do znaczących przedmiotów własnego dziedzictwa archeologicznego, w szczególności stanowisk archeologicznych i zachęcać do publicznej ekspozycji wybranych obiektów archeologicznych" (art. 9, pkt ii). Podejmowanie działalności edukacyjnej ma prowadzić do „wzbudzania i rozwijania w opinii publicznej świadomości wartości dziedzictwa archeologicznego dla zrozumienia przeszłości i niebezpieczeństw, jakie mu zagrażają" (art. 9, pkt i). Konieczność upowszechniania wiedzy na temat przeszłości wskazuje także „Zbiór zasad postępowania i norm etycznych środowiska archeologów w Polsce" z 2004 r., gdzie w punkcie IV czytamy: „archeolog powinien podejmować działania polegające na informowaniu opinii publicznej zarówno o wynikach konkretnych przedsięwzięć badawczych, jak i ogólnych celach i metodach zdobywania wiedzy o pradziejach, przez wykorzystywanie różnorodnych dostępnych środków informacji, takich jak audycje - radiowe i telewizyjne, wywiady prasowe, publikacje popularno-naukowe - programy szkolne i inne inicjatywy edukacyjne".

Działalność upowszechniająca nie powinna ograniczać się jedynie do publikowania wyników badań m.in. w czasopismach czy innych publikacjach, lecz w jej w skład powinny wchodzić inne działania o różnym zakresie, skierowane do róż- 
nych odbiorców: m.in. organizacja seminariów czy konferencji, działalność wydawnicza, prezentacje i odczyty, promocja prowadzonych badań i prezentacja ich wyników w skali np. poszczególnych regionów kraju czy inne formy działań edukacyjnych (np. Jameson 1997; Chowaniec 2010; Corbishley 2011; Okamura, Matsuda 2011). Jak zauważa Mirosława Pluta-Olearnik (2010, s. 22), ważne jest opracowanie przez poszczególne jednostki podejmujące tego rodzaju działania systemu komunikacji z otoczeniem, który będzie „pasem transmisyjnym” dla informowania oraz upowszechniania osiągnięć naukowych i prowadzonych badań. W rezultacie działania takie powinny skutecznie wspierać transfer wiedzy i komercjalizację wyników badań prowadzonych przez te jednostki.

Udostępnianie dziedzictwa archeologicznego szerokiej publiczności oraz popularyzacja wiedzy w tym temacie stanowią więc jedno $\mathrm{z}$ ważniejszych celów i podstaw jego ochrony i zarządzania. U podstaw ochrony leży więc przede wszystkim popularyzacja i mądra edukacja na temat dziedzictwa, jego wartości i znaczenia. Tylko przez zwiększanie wiedzy i świadomości w społeczeństwie na temat tego, jak cenne jest dziedzictwo archeologiczne, a także konieczności jego ochrony, archeologia jest w stanie zaangażować $\mathrm{w}$ ten proces szersze kręgi społeczne, z korzyścią dla dziedzictwa kulturowego oraz społeczeństwa.

\section{UPOWSZECHNIANIE WYNIKÓW BADAŃ W PROJEKCIE „NIEINWAZYJNE ROZPOZNANIE POTENCJALU ZASOBÓW ARCHEOLOGICZNYCH REJONU BOBOLIC, WOJ. ZACHODNIOPOMORSKIE": REALIZACJE}

Istotnym elementem projektu było określenie możliwości wykorzystania informacji generowanych za pośrednictwem nieinwazyjnych metod badawczych w upowszechnianiu i popularyzowaniu wiedzy na temat zasobów dziedzictwa archeologicznego regionu szerszym kręgom społecznym oraz ich potencjalnego wykorzystania w jego turystycznym rozwoju. Wspominano wyżej, że „Konwencja Maltańska" zobowiązała Polskę, aby promować publiczny dostęp do znaczących przedmiotów własnego dziedzictwa archeologicznego, w szczególności zaś stanowisk archeologicznych oraz zachęcać do publicznej ekspozycji wybranych miejsc zabytkowych. Wynika to także ze wspominanej wyżej koncepcji publicznej własności dziedzictwa archeologicznego. Niemniej w praktyce określoną trudnością w korzystaniu z jego zasobów jest często brak wśród mieszkańców tych terenów i władz lokalnych wiedzy o nich.

Podejmowane w projekcie działania popularyzatorskie miały więc na celu poszerzenie grona osób zainteresowanych i rozumiejących potrzebę ochrony zasobów dziedzictwa archeologicznego, tym samym zaś rozwijanie świadomości społecznej w zakresie jego wartości, jak również konieczności jego ochrony i udostępniania, 
zgodnie z zasadą zrównoważonego rozwoju. Warte podkreślenia jest to, że o ile podjęte działania wpisywały się $\mathrm{w}$ zakres standardowych inicjatyw popularyzatorskich, zostały one zrealizowane w sposób kompleksowy. Obejmowały one inicjatywy informujące opinię publiczną o rezultatach badań, jak i ogólnych celach i metodach pozyskiwania wiedzy o pradziejach za pomocą metod nieinwazyjnych przez publikowanie informacji $\mathrm{w}$ serwisach internetowych, zamieszczanie informacji w prasie lokalnej oraz w lokalnych mediach. Odbiorcami projektu byli bowiem nie tylko specjaliści, ale również mieszkańcy tego regionu, w tym dzieci i młodzież, lokalne stowarzyszenia, leśnicy - środowisko, z którym współpraca stanowi potencjalne pole do wspólnych inicjatyw, jak również władze samorządowe. Projekt uwzględniał także podejmowanie działań edukacyjnych w zakresie wykorzystania zintegrowanych badań nieinwazyjnych $\mathrm{w}$ archeologii oraz dobrych praktyk upowszechniania wiedzy na temat dziedzictwa archeologicznego na podstawie danych geoprzestrzennych. Ważnych jego elementem było ukazanie, w jaki sposób można wykorzystać wiedzę o przeszłości oraz lokalne dziedzictwo archeologiczne do budowy przyszłości tego regionu. Opierało się to na przeświadczeniu, że zasoby archeologiczne mogą być istotnym symulatorem lub czynnikiem rozwoju, przy czym ważną rolę w tym kontekście odgrywają nie tyle same zasoby, co raczej ich interpretacja oraz kontekst wykorzystania. Tym samym odpowiednio zinterpretowane zasoby archeologiczne mogą się wiązać z rozwojem w kilku dziedzinach: ochronie zabytków, badaniach naukowych, gospodarce, turystyce oraz edukacji (Rączkowski 2002, s. 69-78).

\section{Seminarium naukowe: „Nieinwazyjne rozpoznanie zasobów dziedzictwa archeologicznego - potencjał i możliwości" ${ }^{4}$}

1 czerwca 2015 r. w Instytucie Prahistorii UAM w Poznaniu odbyło się seminarium naukowe: „Nieinwazyjne rozpoznanie zasobów dziedzictwa archeologicznego - potencjał i możliwości". Wzięło w nim udział kilkadziesiąt osób, zarówno uczestników i jednocześnie wykonawców projektu, jak również inne osoby, głównie ze środowiska naukowego - pracownicy Instytutu Prahistorii UAM w Poznaniu, przedstawiciele Nadleśnictwa w Polanowie, a także studenci i doktoranci archeologii z Instytutu Prahistorii UAM w Poznaniu. Wygłoszone prelekcje dotyczyły m.in. wyników przeprowadzonych badań, jak również szerszych zagadnień wynikłych $\mathrm{w}$ trakcie ich realizacji. Seminarium miało bowiem na celu stanie się forum krytycznej dyskusji na temat m.in. oceny skuteczności metod nieinwazyjnych przy rozpoznawaniu struktur pradziejowych, wartości metod badań nieinwazyjnych w polityce ochrony i zarządzania dziedzictwem archeologicznym oraz integracji metod nie-

\footnotetext{
${ }^{4}$ http://archeo.amu.edu.pl/bobolice/konferencje_archiwum_czerwiec_2015.htm, dostęp: 25.10.2016 r.
} 
inwazyjnych. W trakcie seminarium podjęte zostało również zagadnienie oceny potencjału zasobów dziedzictwa archeologicznego pod kątem turystycznym, a także kwestia dobrych praktyk upowszechniania wiedzy na ich temat, w tym głównie na podstawie informacji generowanych za pośrednictwem nieinwazyjnych metod teledetekcyjnych. Tym samym zmierzało ono do podejmowania wspólnych działań i usprawnienia systemu ochrony i zarządzania dziedzictwem archeologicznym, mając $\mathrm{w}$ intencji integrację działań naukowo-badawczych, edukacyjnych oraz popularyzatorskich.

\section{Sesja popularno-naukowa: „Dziedzictwo archeologiczne ziem bobolickiej i polanowskiej: rozpoznanie, potencjal, perspektywy"5}

W dniu 28 października 2015 r. w Izbie Edukacyjnej przy Nadleśnictwie w Bobolicach odbyła się sesja popularno-naukowa pt. „Dziedzictwo archeologiczne ziem bobolickiej i polanowskiej: rozpoznanie, potencjał, perspektywy”. Została ona zorganizowana we współpracy z Towarzystwem Ekologiczno-Kulturalnym w Bobolicach oraz Nadleśnictwem w Bobolicach. Sesja została objęta honorowym patronatem Burmistrz Bobolic - Pani Mieczysławy Brzozy - oraz patronatami ze strony Nadleśnictwa w Polanowie i Muzeum w Koszalinie. Zorganizowano ją nie tyko z myślą o naukowcach - archeologach czy historykach, ale również o pracownikach nadleśnictw, przedstawicielach miejscowych władz, mieszkańcach, pasjonatach archeologii oraz wszystkich innych zainteresowanych. Licznie przybyli na nią m.in. radni Rady Miejskiej, pracownicy Nadleśnictw w Bobolicach i Polanowie, przedstawiciele placówek oświatowych, ośrodka kultury, biblioteki, lokalnych stowarzyszeń i mieszkańcy Bobolic. Inicjalny cel, jakim było dotarcie z informacją do szerokiego i zróżnicowanego grona odbiorców oraz integracja różnych środowisk w działaniach na rzecz ochrony i zarządzania dziedzictwem archeologicznym, został tym samym osiągnięty, o czym świadczy zarówno frekwencja uczestniczących w niej osób, jak i pozytywny, społeczny odzew inicjatywy.

Wystąpienia prezentowane $\mathrm{w}$ trakcie sesji dotyczyły problematyki podejmowanej w ramach realizowanego projektu badawczego. Referenci przedstawiali także wyniki badań, $\mathrm{w}$ tym głównie z zastosowaniem nowoczesnych, nieinwazyjnych metod przy rozpoznawaniu struktur pradziejowych, prezentowali dokonane odkrycia terenowe w postaci m.in. nowoodkrytych pradziejowych kurhanów i cmentarzysk kurhanowych, systemów okopów z czasów II wojny światowej, zajmowali się problematyką ochrony dziedzictwa archeologicznego regionu, jak również akcentowali możliwości jego popularyzacji i wykorzystania w rozwoju turystycznym regionu (ryc. 1). Podczas sesji zaprezentowany został także poster, ilustrujący m.in. zasto-

\footnotetext{
${ }^{5}$ http://archeo.amu.edu.pl/bobolice/konferencje.htm, dostęp: 25.10.2016 r.
} 
sowane w trakcie badań archeologiczne metody prospekcji terenu, uzyskane w ich trakcie rezultaty oraz proponowane formy wykorzystania informacji o stanowiskach archeologicznych dla rozwoju turystycznego regionu Bobolic. Po zakończeniu sesji był on prezentowany w budynku Urzędu Miejskiego w Bobolicach. Na potrzeby sesji przygotowana została również broszura informacyjna o wybranych stanowiskach i obiektach archeologicznych, z wykorzystaniem materiału ilustracyjnego i graficznych wizualizacji, opracowanych na podstawie zasobów uzyskanych w wyniku nieinwazyjnych badań archeologicznych, podejmowanych w ramach projektu (Pawleta 2015b).

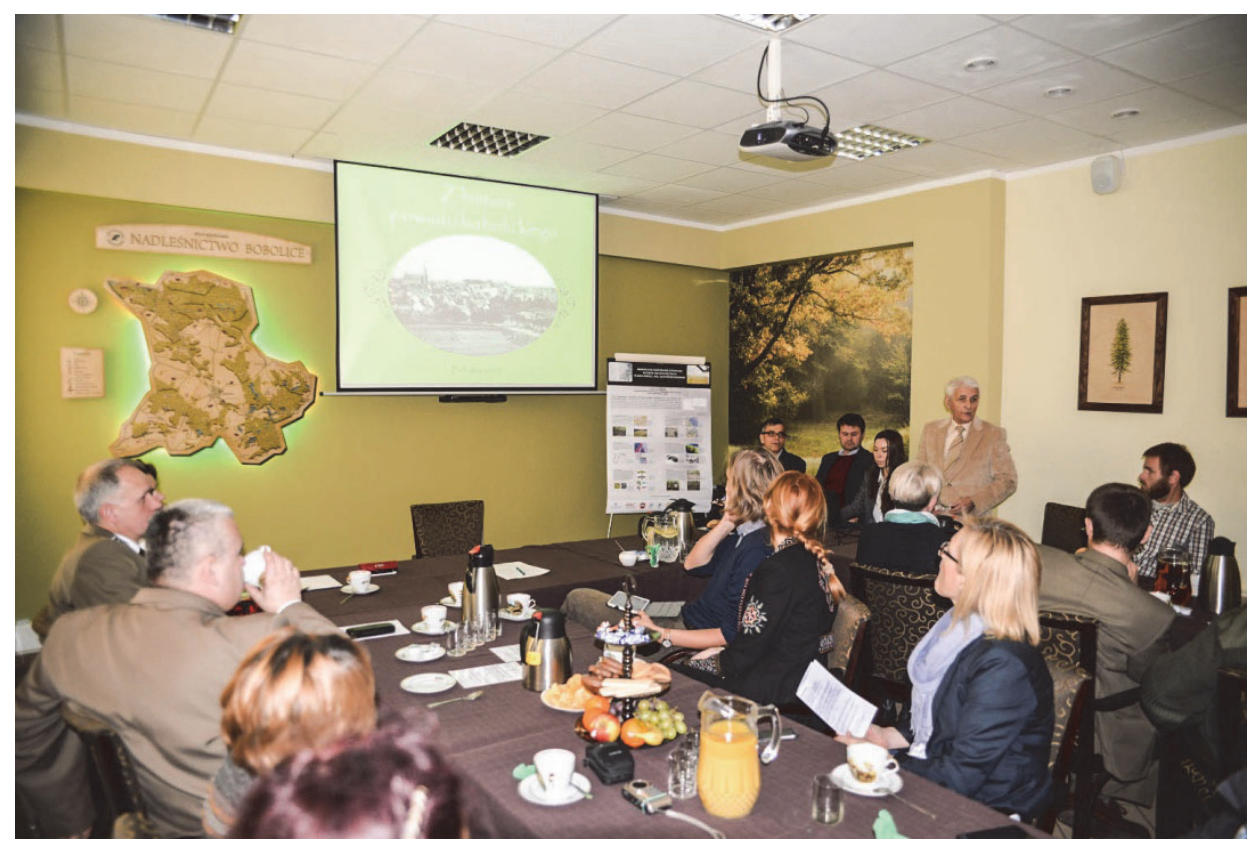

Ryc. 1. Uczestnicy sesji popularno-naukowej „Dziedzictwo archeologiczne ziem bobolickiej i polanowskiej: rozpoznanie, potencjał, perspektywy w Bobolicach” podczas obrad (fot. P. Kaźmierczak)

Fig. 1. The participants of the popular-science conference "Archaeological heritage in the Bobolice and Polanów regions: survey, potential, prospects’ during the presentations (Photo P. Kaźmierczak

\section{Lekcje na temat dziedzictwa archeologicznego regionu w szkołach}

W ramach działalności towarzyszącej realizacji projektu i upowszechniania jego wyników, a także zaplanowanych w jego trakcie działań edukacyjnych, opracowano i przeprowadzono lekcje na temat dziedzictwa archeologicznego ziemi bobolickiej oraz możliwości jego rozpoznania przy zastosowaniu nowoczesnych, archeologicz- 
nych i nieinwazyjnych metod badawczych. Zajęcia przeprowadzono w Gimnazjum im. Agaty Mróz-Olszewskiej w Bobolicach oraz w Szkole Podstawowej im. Henryka Sienkiewicza w Bobolicach. Spotkały się one z dużym zainteresowaniem ze strony nauczycieli, a przede wszystkim uczniów (ryc. 2). Przeprowadzone lekcje miały na celu przybliżenie informacji o pradziejach ziemi bobolickiej oraz ochronie zasobów archeologicznych tego regionu. Równoległym celem była prezentacja realizowanego projektu naukowego razem ze wstępnymi wynikami badań. Podczas spotkań przedstawiono podstawowe informacje na temat archeologii, pracy archeologów oraz dziedzictwa archeologicznego. Wykłady miały na celu nie tylko zaprezentowanie najnowszych metod badawczych, zastosowanych w ramach projektu, ale także zainteresowanie dzieci i młodzieży dziedzictwem historycznym regionu. Uczniowie dowiedzieli się m.in., co to jest teledetekcja, jak wykorzystywane są zobrazowania satelitarne $\mathrm{w}$ archeologii, po co $\mathrm{w}$ badaniach jest stosowane lotnicze i naziemne skanowanie laserowe.

Dużym zainteresowaniem cieszył się również bezpośredni kontakt młodzieży z zabytkami - młodzież mogła zbliżyć się do dziedzictwa podczas prezentowania fragmentów pradziejowych naczyń ceramicznych - co sprzyjało realizacji zasady,

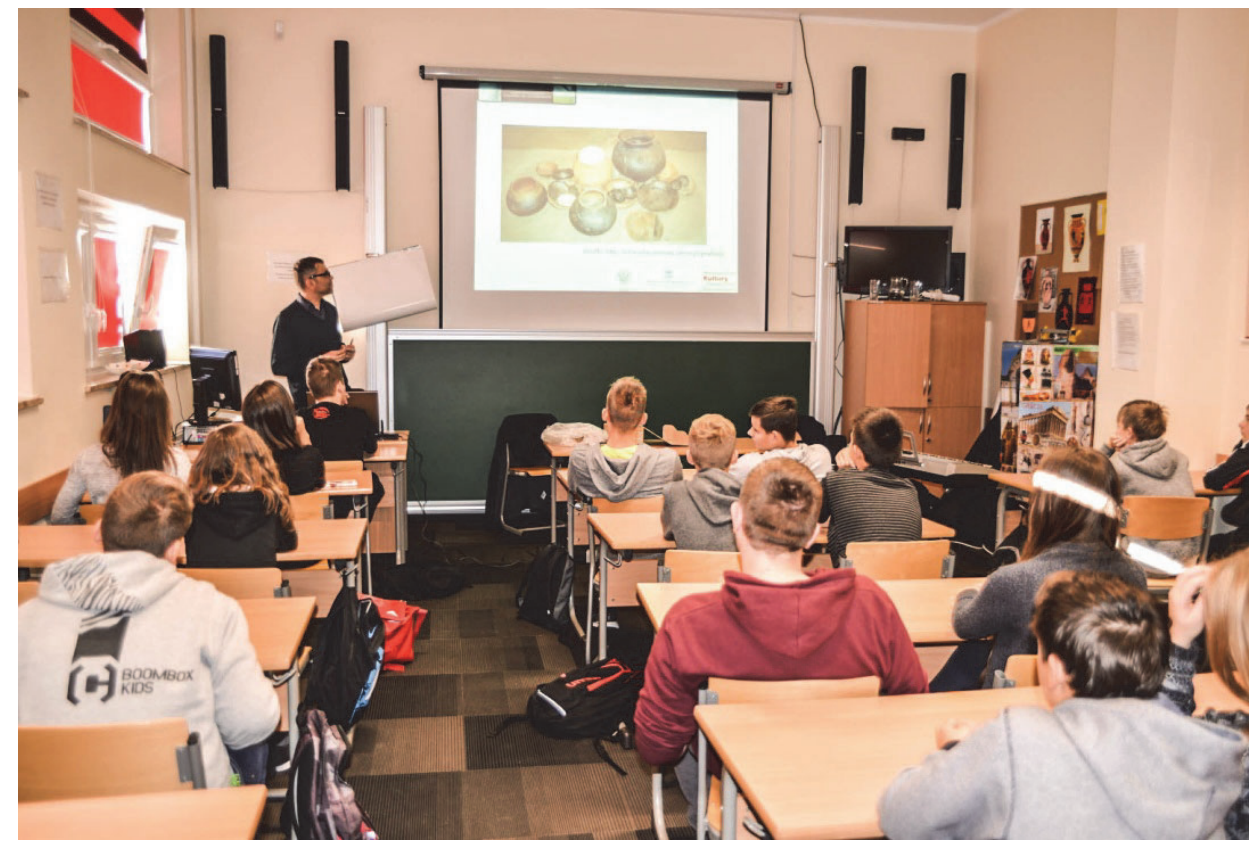

Ryc. 2. Prezentacja poświęcona społecznej wrażliwości i potocznej wiedzy o zabytkach: zajęcia dla uczniów klasy 3. gimnazjum w Bobolicach (fot. R. Zapłata)

Fig. 2. Presentation on social awareness and common knowledge about monuments: a lesson with grade 3 students from the junior high school in Bobolice (Photo R. Zapłata) 
„aby wziąć zabytek do ręki [...] poczuć tradycję i historię” (Chowaniec 2010, s. 210). W formie wykładu i prezentacji multimedialnych zapoznano także uczniów z działaniem skanera laserowego, przetwarzaniem danych cyfrowych i ich wizualizacją. Ponadto podczas spotkań uczniowie mogli się dowiedzieć, czym jest Geoportal - Geoportal 2, dzięki któremu usługi infrastruktury informacji przestrzennej dostępne są również dla osób fizycznych i prawnych oraz innych jednostek organizacyjnych $^{6}$. Dzieląc się wiedzą na temat zasobów dostępnych online, zachęcano młodzież do samodzielnego poznawania regionu przez pryzmat nowoczesnych danych teledetekcyjnych. W trakcie wykładów został również przekrojowo omówiony ISOK (Informatyczny System Osłony Kraju - ISOK) przed nadzwyczajnymi zagrożeniami, a zwłaszcza zasób danych, który powstał podczas realizacji ww. projektu? Ponadto na bazie wyniesionych doświadczeń przygotowano koncepcję oferty dydaktycznej razem z pakietem edukacyjnym dla nauczycieli szkół, możliwym do wykorzystania w przyszłości podczas nauczania historii.

\section{Dzialania promocyjne i wydawnicze}

Promocja zadania była realizowana na kilku zintegrowanych ze sobą płaszczyznach. Jedną z nich była aktualizowana strona internetowa projektu, przygotowana w języku polskim oraz częściowo angielskim. Ponadto informacje na temat projektu i jego poszczególnych działań oraz uzyskanych w trakcie badań wyników ukazywały się w różnych serwisach czy portalach internetowych. Kierując się potrzebą dotarcia do szerszego grona odbiorców, przygotowywano także artykuły, które ukazały się w lokalnej prasie: Archeolodzy na ziemi bobolickiej (Bobolickie Wiadomości Samorzadowe, nr 11, listopad 2015, s. 5) oraz Archeologiczne „skarby” ziemi bobolickiej (Znad Chocieli, 3-4, s. 75-76; lipiec-grudzień 2015, s. 1, 3-5).

W ramach działań promocyjnych opracowano także ilustrowaną broszurę informacyjną Dziedzictwo archeologiczne rejonu Bobolic o wybranych zasobach archeologicznych rejonu. Zawiera ona krótkie teksty na temat dziedzictwa archeologicznego regionu i konieczności jego ochrony, rodzajów stanowisk archeologicznych występujących na tym obszarze oraz zastosowania nowoczesnych metod nieinwazyjnych w ich rozpoznaniu i identyfikacji. Oprócz wersji drukowanej została ona także udostępniona $\mathrm{w}$ formie cyfrowej na stronie internetowej projektu ${ }^{8}$ (ryc. 3).

\footnotetext{
${ }^{6} \mathrm{http} / / /$ www.geoportal.gov.pl/pl/o-geoportalu/informacje-o-projekcie, dostęp: $25.10 .2016 \mathrm{r}$.

${ }^{7} \mathrm{http}: / /$ www.isok.gov.pl/pl/, dostęp: 25.10.2016 r.

${ }^{8}$ Broszura do pobrania pod adresem: http://archeo.edu.pl/bobolice/broszura2.pdf, dostęp: 25.10. $2016 \mathrm{r}$.
} 


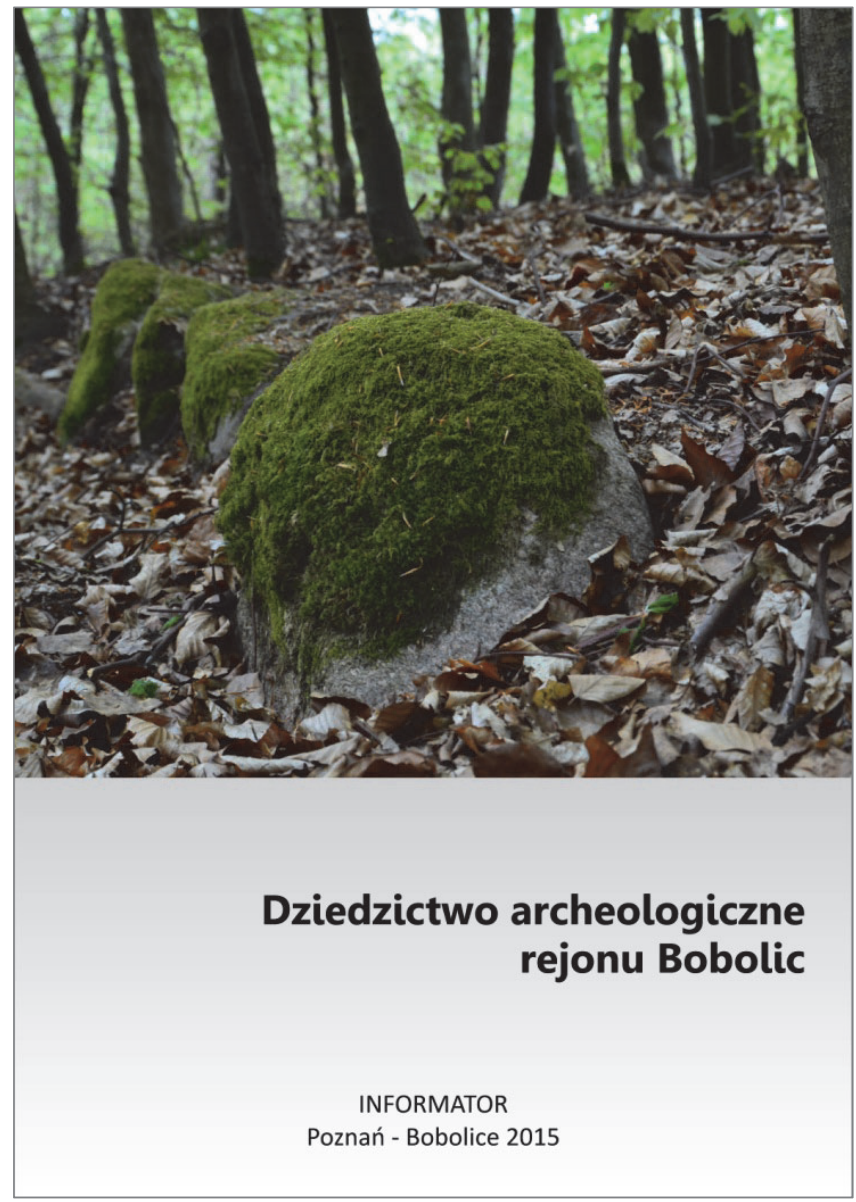

Ryc. 3. Broszura informacyjna „Dziedzictwo archeologiczne rejonu Bobolic” przygotowana w ramach projektu

Fig. 3. Information leaflet 'Archaeological heritage of the Bobolice region', issued under the project

Przygotowane zostały także postery, prezentujące m.in. zastosowane $\mathrm{w}$ trakcie badań metody, uzyskane wyniki oraz proponowane formy wykorzystania informacji o stanowiskach archeologicznych dla rozwoju turystycznego regionu, uwypuklające ich walory jako potencjalnych atrakcji turystycznych. Były one prezentowane m.in. na „21th European Association of Archaeologists Conference” w Glasgow, podczas „III Targów konserwacji i restauracji zabytków oraz ochrony, wyposażenia archiwów, muzeów i bibliotek” w Warszawie, w trakcie konferencji „Cyfryzacja w naukach o przeszłości i ochronie zabytków - analiza potencjału i zagrożeń" na UKSW w Warszawie, w trakcie sesji popularnonaukowej w Bobolicach oraz w holu Urzędu Miejskiego w Bobolicach. 
Finalnie, jako podsumowanie działań, opublikowana została recenzowana monografia naukowa w postaci ebooka pt. Nieinwazyjne rozpoznanie zasobów dziedzictwa archeologicznego: potencjał i możliwości" (Pawleta, Zapłata 2015) ${ }^{9}$. Jej celem jest zaprezentowanie wyników badań nieinwazyjnych wykorzystanych do rozpoznania zasobów archeologicznych okolic Bobolic oraz przedstawienie wykorzystanych metod badawczych razem z ich wartościami poznawczymi. Rozdziały prezentują szczegółowe wyniki poszczególnych rodzajów prospekcji nieinwazyjnej oraz omawiają ich wartość poznawczą, zawierają także ocenę wartości danych i stosowanych metod. W książce znajdują się także teksty poświęcone problematyce społecznego znaczenia odkrytego dziedzictwa archeologicznego i historycznego oraz popularyzacji wiedzy na jego temat wśród różnych grup społecznych, jak również zawierające pewne wytyczne dla działań mających na celu ochronę i zarządzanie dziedzictwem archeologicznym.

\section{FORMY UPOWSZECHNIANIA DZIEDZICTWA ARCHEOLOGICZNEGO: PROPOZCJE}

Pozytywnym rezultatem przeprowadzonych w trakcie projektu prac było rozpoznanie i zinwentaryzowanie szeregu nowych stanowisk archeologicznych, znajdujących się głównie na terenach leśnych, ale również pozytywna weryfikacja wielu już znanych. Do najciekawszych należy zaliczyć odkrycie kilku domniemanych cmentarzysk pradziejowych o trudnej do ustalenia chronologii, z czytelnymi na powierzchni konstrukcjami/brukami kamiennymi oraz skupisk kurhanów kamienno-ziemnych, zlokalizowanych w lasach. Pochodzą one przypuszczalnie z okresu wczesnego średniowiecza, jednak sądząc na podstawie analogii do znanych tego typu konstrukcji, prawdopodobnie niektóre $\mathrm{z}$ nich mogą być z okresu neolitu (zob. Borkowski, Kasprzak, Kuczkowski 2015; Kaźmierczak, Zapłata 2015).

Potencjalnie istnieje wiele możliwości zagospodarowania i upowszechniania wiedzy na temat obiektów/stanowisk archeologicznych oraz ich wykorzystania w rozwoju turystyki archeologicznej w rejonie Bobolic. Dotyczy to szczególnie stanowisk o własnej czytelnej formie terenowej, dobrze zachowanych, znajdujących się głównie na terenach leśnych, których eksponowanie powinno być połączone z eksplorowaniem walorów przyrodniczych i kulturowych tych ziem. Przy czym wysunięte poniżej propozycje należy potraktować jako pewne sugestie dotyczące przyszłych potencjalnych działań, mających na celu udostępnianie zasobów dziedzictwa archeologicznego tych okolic. Ze względu jednak na specyfikę tego dziedzictwa, wymagają one uzgodnienia sposobu użytkowania i udostępniania stanowisk

\footnotetext{
${ }^{9}$ Publikacja do pobrania pod adresem: http://e-naukowiec.eu/nieinwazyjne-rozpoznanie-zasobowdziedzictwa-archeologicznego-potencjal-i-mozliwosci/, dostęp: 25.10.2016 r.
} 
archeologicznych ze służbą ochrony zabytków, ponieważ zawsze istnieje obawa przed ich dewastacją (zob. Józefowska 2002).

(1) Oznakowanie co ciekawszych i bardziej eksponowanych w terenie stanowisk, w tym głównie grodzisk oraz stanowisk kurhanowych, oczyszczenie ich terenu oraz ustawienie przy nich tablic czy plansz informacyjnych. Pozwoliłoby to na organizację ruchu turystycznego w pobliżu zabytków. Poprawnie przygotowane oznakowanie i tablice informacyjne gwarantują odpowiednią organizację dostępu do zabytków, która respektuje zarówno potrzeby ich ochrony, jak i wymogi ruchu turystycznego, naukową interpretację ich pierwotnej funkcji i kształtu, a niekiedy też różne form rekonstrukcji (rysunkowe, modelowe, wirtualne) oraz promocję samych obiektów (Rączkowski 2002, s. 73).

Tego typu oznakowanie winno znaleźć się m.in. przy znanym ze wcześniejszych badań wczesnośredniowiecznym grodzisku w Górawinie, stan. 1. Jest to rozległe, wyżynne, pierścieniowate $\mathrm{w}$ kształcie owalu grodzisko $\mathrm{z}$ wypukłym majdanem, $\mathrm{z}$ bardzo dobrze zachowanymi wysokimi wałami o stromych zboczach, otaczających majdan (zob. Olczak, Siuchniński 1968, s. 69-73). Także na uwagę w tym względzie zasługują liczne skupiska kurhanów w rejonie Buszynka (stan. 1), Chocimina oraz Więcemierza (stan. 2, stan. 3, stan. 4). Większość z nowo odkrytych kurhanów posiadała kolisty lub prostokątny kształt o średnicy od 5 do $8 \mathrm{~m}$, w wielu przypadkach posiadały one regularne obstawy kamienne.

(2) Utworzenie rezerwatów bądź skansenów archeologicznych w przypadku najbardziej wartościowych zabytków/stanowisk archeologicznych bądź ich zespołów. Będzie to stanowić tradycyjną formę zachowania i eksponowania dziedzictwa archeologicznego in situ, czego przykłady znane są w okolicach Bobolic. Według definicji Kazimierza Piwockiego (1961, s. 3):

rezerwatem jest więc zabytek, który nie pełni żadnych bieżących funkcji użytkowych, a równocześnie jest przygotowany materialnie (mam tu na myśli przede wszystkim urządzenia komunikacyjne) i organizacyjnie (mam tu na myśli dozorców i przewodników) do służenia osobom i grupom odwiedzającym rezerwat. Zabytkiem może być np. grodzisko widoczne w terenie wśród pól czy mokradeł, ale rezerwatem staje się dopiero wtedy, gdy umożliwi się do niego dostęp, przez odpowiednie prace przygotuje właściwą dydaktycznie „ekspozycję” założenia i wreszcie zorganizuje się stały dozór i dostateczną obsługę zwiedzających.

Podstawę ich ekspozycji stanowi oryginalny zabytek bądź ich zespół, na którym prowadzono badania wykopaliskowe, prezentowane in situ, czyli w miejscu znalezienia, zaś podstawowa rola rezerwatu polega na ochronie i upublicznianiu dziedzictwa archeologicznego (Rajewski 1968, s. 429; 1980, s. 296). W przypadku wielu rezerwatów oryginalne zabytki są często uzupełnione o ich pełnowymiarowe rekonstrukcje, wzniesione zgodnie z ustaleniami naukowymi, na miejscu wykopalisk albo $\mathrm{w}$ ich bezpośrednim sąsiedztwie. Towarzyszą im rozmaite systemy informacyjne oraz zabezpieczające. 
Dobrym wzorcem do naśladowania w tym zakresie są m.in. rezerwat archeologiczno-przyrodniczy „Kręgi kamienne w Grzybnicy” - cmentarzysko kurhanowe z kręgami kamiennymi z I-III wieku n.e., licznie odwiedzane przez turystów (Wołągiewicz, Hahuła 2000), cmentarzysko megalityczne w miejscowości Borkowo na Pomorzu Środkowym (gm. Malechowo), którego główną atrakcją są zrekonstruowane grobowce megalityczne (Malinowska-Sypek, Sypek, Sukniewicz 2010, 65-651) czy cmentarzysko kurhanowe w Żydowie, stan. 8 (gm. Polanów). Kilka lat temu w ramach projektu „Kurhany we wsi Żydowo” uporządkowano teren badanego jeszcze w latach 60. XX w. kurhanowego stanowiska: usunięto porastające go zakrzaczenia oraz śmieci, ustawiono tablice informacyjne, zrekonstruowano jeden z kurhanów, zrobiono ścieżki do zwiedzania, ogrodzono teren nekropolii, zainstalowano pewne elementy, tj. tablice, ławki, drogowskazy oraz kosze na śmieci. Aktualnie obiekt jest udostępniony zwiedzającym i cieszy się zainteresowaniem turystów (Tota 2010, s. 137).

Tego typu ochroną $-\mathrm{z}$ racji na stan zachowania oraz grupowanie się na niewielkiej przestrzeni w wyraźny zespół - powinno zostać objęte skupisko nieznanych wcześniej dziewięciu kurhanów z wyraźnie prostokątnymi obstawami kamiennymi i nasypami ziemnymi o wysokości 1-1,5 m, odkryte na terenie pasieki w Leśnictwie Łanki Buszynko Pierwsze (stan. 2). Wśród kurhanów wystąpiły dwa znacznie większe (ok. $15 \mathrm{~m} \times 6 \mathrm{~m}$ ), pozostałe siedem jest mniejszych rozmiarów (ok. $6 \mathrm{~m} \times 4 \mathrm{~m}$ ) (ryc. 4).

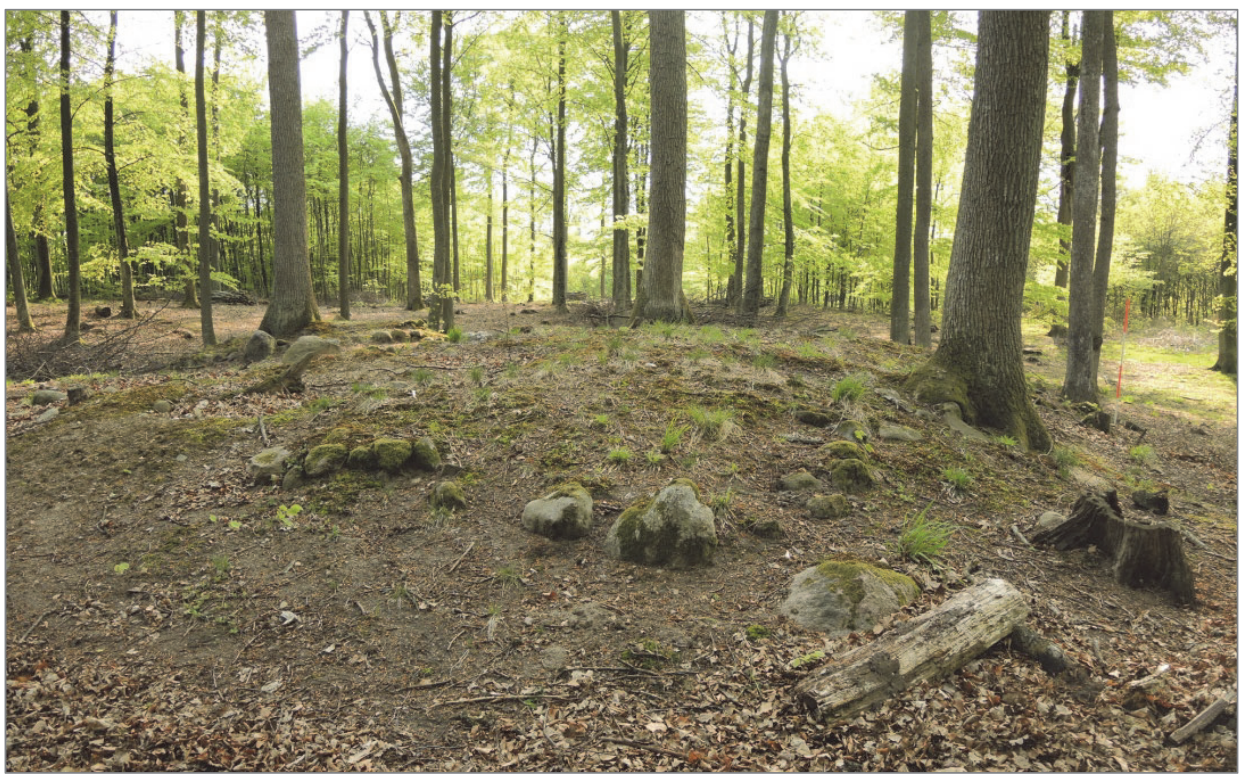

Ryc. 4. Skupisko kurhanów kamienno-ziemnych na terenie Leśnictwa Łanki (Fot. M. Pawleta)

Fig. 4. A cluster of stone and earth barrows in the area of the Łanki forestry commission (Photo. M. Pawleta) 
(3) Opracowanie szczegółowych materiałów informacyjnych o wybranych stanowiskach archeologicznych regionu. Zaczątkiem może być przygotowana $\mathrm{w}$ ramach projektu broszura informacyjna pt. Dziedzictwo archeologiczne rejonu Bobolic. Zasadne wydaje się także opracowanie ilustrowanego przewodnika archeologicznego po ziemi bobolickiej, zawierającego podstawowe informacje na temat stanowisk, wykorzystującego zasób ilustracyjny i wizualizacje opracowane na podstawie materiałów uzyskanych $\mathrm{w}$ wyniku badań niedestrukcyjnych, udostępnianego $\mathrm{w}$ wersji papierowej (np. w dziale promocji w Urzędzie Miejskim w Bobolicach, w nadleśnictwach) oraz cyfrowej (w formacie pdf.), możliwej do darmowego pobrania ze strony internetowej.

(4) Poza tradycyjną formą zachowania i eksponowania dziedzictwa archeologicznego in situ, jego promocję oraz prezentację doskonale może wspomóc zasób cyfrowy, zachęcający i informujący o nim, nie wypierając zarazem zainteresowania oryginalnymi zabytkami oraz nowoczesne technologie. Istotnym elementem jest możliwość wykorzystania generowanych za pośrednictwem nowych technologii informacji w upowszechnianiu i popularyzowaniu wiedzy na temat zasobów dziedzictwa archeologicznego, jak również samych technologii (np. Lytras 2011; Ciejka 2012; Giaccardi 2012; Chowaniec 2013). Współczesne społeczeństwo, coraz częściej posługujące się urządzeniami elektronicznymi w życiu codziennym, winno być postrzegane jako odbiorca, dla którego takie urządzenia są swego rodzaju medium, za pomocą których wchodzi z relacje z otaczającym je światem.

Jednym z podstawowych elementów w tym zakresie winno być stworzenie interaktywnej, aktualizowanej strony internetowej dotyczącej dziedzictwa archeologicznego regionu, jego poszczególnych form, zagadnień ochrony, popularyzacji czy wydarzeń związanych zabytkowymi obiektami. Strona powinna być zintegrowana z mediami społecznościowymi (m.in. Facebook, Tweeter, Instagram), dającymi ich użytkownikom możliwość interaktywnego uczestniczenia w wydarzeniach.

Ponadto warte rozważenia jest oznakowanie wybranych stanowisk przy pomocy kodów QR (ang. QR Code - Quick Response Code). W celu poznania treści kryjącej się za kodem QR (zawierających dowolny tekst, adres strony internetowej, pozycję geograficzną, dane kontaktowe itd.). wystarczy skierować na niego urządzenie (smartfon, tablet) z uruchomioną aplikacją. W archeologii podejmowane są skuteczne próby umiejscawiania QR kodów w okolicach badanych stanowisk bądź na samych stanowiskach, co pozwala wprowadzić informacje do szerszego kręgu odbiorców, którzy, przybliżając telefon do kodu, uzyskują sporo wiadomości o terenie, na którym się znajdują czy stanowisk, obiektów bądź ich rekonstrukcji, które zwiedzają (no. Chowaniec 2013).

Dużym ułatwieniem w zwiedzaniu dziedzictwa regionu byłoby także opracowanie aplikacji mobilnej na smartfona, która określa umiejscowienie obiektów zabytkowych w najbliższej okolicy użytkownika, udostępnia również najważniejsze wcześniej opracowane informacje na temat danych zabytków (zob. Koźniewski 2014). 
(5) Innym elementem mogłoby być połączenie walorów archeologicznych, historycznych oraz przyrodniczych regionu i stworzenie na tej bazie oferty edukacyjno-rekreacyjnej (ścieżki rowerowe, trasy spacerowe połączone ze stanowiskami archeologicznymi) czy szlaków tematycznych dla różnych grup odbiorców. Wymaga to powiązania ich z odpowiednią infrastrukturą turystyczną, która nota bene już istnieje w regionie (szlaki, gospodarstwa agroturystyczne, punkty gastronomiczne itd.), a także przygotowania nie tylko miejsc zabytkowych, ale tras wycieczek pieszych, rowerowych, które będą łączyć tego typu atrakcje w regionie (Rączkowski 2002, s. 76; Wrzesiński 2008, s. 173-184). Obecność w okolicach Bobolic stanowisk archeologicznych o własnej czytelnej formie terenowej, jak grodziska wczesnośredniowieczne czy kurhany stanowi szansę dla realizowania działań mających na celu popularyzację oraz ochronę dziedzictwa archeologicznego tego regionu. Połączenie zasobów archeologicznych z atrakcyjnością tutejszego środowiska przyrodniczego oraz walorami krajobrazowymi okolicy może stanowić bodziec do rozwoju turystyki. Niemniej rozmaitość obiektów archeologicznych wymaga konieczności zindywidualizowanego podejścia do nich, co pozwala na ich zabezpieczenie i udostępnienie.

(6) Kolejnym aspektem o dużych walorach popularyzatorskich może być „ożywienie" stanowisk archeologicznych. Poziom atrakcyjności turystycznej nie wynika bowiem tylko z obecności obiektów zabytkowych, lecz ma związek z ich ożywianiem, przez organizację plenerowych imprez popularyzujących wiedzę o przeszłości i regionie, pokazów w ramach archeologii eksperymentalnej, festynów archeologiczno-historycznych, prezentacji dawnych rzemiosł, które mogłyby być organizowane przy pewnych stanowiskach. Jako wzór do naśladowania można przywołać organizowany corocznie na terenie rezerwatu w Grzybnicy festyn „Goci na Kamiennych Kręgach” czy „Sobotę na grodzisku” we Wrześnicy (Wróblewska 2008).

(7) Ponadto warto byłoby zorganizować w lokalnych placówkach kulturalnych (np. W Muzeum Regionalnym w Bobolicach) wystawę dotyczącą dziedzictwa archeologicznego regionu ${ }^{10}$. Proponowana wystawa mogłaby obejmować prezentację poczynionych odkryć w formie wystawy plansz edukacyjnych, wielkoformatowych fotografii, uzupełnionych o postery, artefaktów i ich kopii. Towarzyszyć jej powinien katalog wystawy zawierający informacje na temat prezentowanych rzeczy, a także dziedzictwa archeologicznego regionu. Wystawę można by również wzbogacić o folder informacyjny na temat zrealizowanego projektu - podejmowanych

\footnotetext{
${ }^{10}$ Tego typu czasowa ekspozycja została zorganizowana już po zakończeniu pisania niniejszego artykułu. Wystawa pt. „Przeszłość się nie skończyła i nadal jest obecna wśród nas. Dziedzictwo archeologiczne rejonu Bobolic" była prezentowana w Muzeum Regionalnym w Bobolicach w okresie od 25 października do 30 listopada 2016 r. Została przygotowana w Instytucie Prahistorii UAM dzięki środkom finansowym oraz $\mathrm{w}$ wyniku działań realizowanych $\mathrm{w}$ ramach europejskiego projektu „NEARCH. A New ways of community-involved archaeology” oraz dzięki przychylności i wsparciu wielu instytucji i osób.
} 
w jego trakcie badań oraz uzyskanych wyników. Ważne przy tym, by wystawa posiadała charakter nie stricte naukowy, lecz miała formę tzw. wystawy ożywionej, uzupełnianej czasowo o inscenizacje, przez co bardziej atrakcyjnej dla zwiedzających.

(8) Wreszcie dużą rolę w upowszechnianiu dziedzictwa archeologicznego regionu i wiedzy o nim mogą odegrać prelekcje, odczyty, jak również sesje popularnonaukowe, skierowane do różnych grup odbiorców. Duże znaczenie i udowodnioną skuteczność na tym polu ma także organizowanie w szkołach lekcji/warsztatów archeologicznych oraz innych zajęć praktycznych przystosowanych dla poszczególnych grup wiekowych. Zajęcia te powinny w przystępny i profesjonalny sposób przekazywać wiedzę na temat archeologii i dziedzictwa archeologicznego regionu. $\mathrm{W}$ trakcie takich zajęć dzieci i młodzież mają szanse na bezpośredni kontakt z profesjonalnie wykonanymi replikami zabytków, w aktywny sposób poznając przeszłość regionu. Tego typu zajęcia dydaktyczne, prowadzone w większości krajów Europy oraz USA, wykazały swą użyteczność i skuteczność. Mogą one odbywać się na terenie przedszkoli, szkół, placówek kulturalno-oświatowych, a także przy wybranych stanowiskach archeologicznych.

\section{PODSUMOWANIE}

Upowszechnianie wiedzy o najdawniejszych dziejach regionu Bobolic i jego materialnym dziedzictwie powinno stać się jednym z elementów lokalnej edukacji, przy czym działania te mogą zyskać liczne grono odbiorców - osób zainteresowanych przeszłością tych okolic. Istniejące zasoby archeologiczne stanowią potencjalną bazę dla rozwoju turystyki archeologicznej w regionie, w tym przede wszystkim turystyki indywidualnej, dzięki której turyści będą mogli przyswoić sobie wiedzę o dziedzictwie archeologicznym i historycznym regionu, w połączeniu z eksponowaniem walorów środowiskowych i geograficznych lokalnych terenów oraz ideę jego ochrony. Przy czym zasoby archeologiczne tego terytorium mogą zainteresować nie tylko turystów, lecz także okoliczną społeczność, ponieważ ich wykorzystanie może wpisać się w strategię rozwoju gminy przez obecność przygotowanych, oznakowanych obiektów archeologicznych i powiązanie ich z promocją, co stanowi istotny warunek rozwoju turystyki archeologicznej. Skuteczne inicjatywy na tym polu będą jednak wymagały współpracy między archeologami, lokalnymi władzami oraz nadleśnictwami, jak również włączania w te działania lokalnej społeczności.

Co istotne, inicjatywy w tym zakresie w dłuższej perspektywie mogą formować wrażliwość społeczną na potrzebę ochrony dziedzictwa archeologicznego i uświadomienie sobie jego roli we współczesnym społeczeństwie, jak również przyczyniać się do budowania tożsamości lokalnej grup społecznych oraz wiązania ludzi z regionalną tradycją. W ten sposób podkreślona zostanie duża rola dziedzictwa archeolo- 
gicznego i jego znaczenie dla mieszkańców, którzy staną się sprzymierzeńcami w realizacji celów archeologii, jak również zaznaczona zostanie współczesna rola i społeczna użyteczność tej dyscypliny.

\section{BIBLIOGRAFIA}

Borkowski J., Kuczkowski A.

2013 Poza szlakiem. Źródła archeologiczne do dziejów małych miast Pomorza Środkowego. Cz. 1, B. woj. koszalińskie. Koszalin: Muzeum w Koszalinie.

Borkowski J., Kasprzak A., Kuczkowski A.

2015 Nieinwazyjne rozpoznanie potencjału zasobów archeologicznych rejonu Bobolic, woj. zachodniopomorskie. W: M. Pawleta, R. Zapłata (red.), Nieinwazyjne rozpoznanie zasobów dziedzictwa archeologicznego: potencjal i możliwości (s. 27-48). Lublin: Wydawnictwo E-naukowiec.

Broński K.

2006 Rola dziedzictwa kulturowego w rozwoju lokalnym. Doświadczenie polskie doby transformacji (po 1989 r.). Zeszyty Naukowe Akademii Ekonomicznej w Krakowie, 706, s. 7-26.

Carman J.

2005 Against Cultural Property. Archaeological Heritage and Ownership. London: Duckworth.

Chowaniec R.

2010 Dziedzictwo archeologiczne $w$ Polsce. Formy edukacji i popularyzacji. Warszawa: Instytut Archeologii UW.

Chowaniec R.

2013 Rozwój edukacji muzealnej. Od wystawiania przedmiotów na agorach i forach po hologramy i kody QR. W: U. Wróblewska, K. Radłowska (red.), Edukacja muzealna. Konteksty teoretyczne i praktyczne (s. 15-28). Białystok: Muzeum Podlaskie w Białymstoku.

Chudziak W., Kaźmierczak R., Niegowski J.

2011 Podwodne dziedzictwo archeologiczne Polski. Katalog stanowisk (badania 2006-2009). Torun: Wydawnictwo Fundacji Amicus Universitatis Nicolai Copernici, Wydawnictwo Uniwersytetu Mikołaja Kopernika.

Ciejka K.

2012 Using the Social Media and New Technologies in the Popularization and Promotion of Archeology. W: W. Więckowski, R. Chowaniec (red.), Archaeological Heritage: Methods of Education and Popularization (BAR International Series 2443, s. 53-58). Oxford: Archaeopress.

Corbishley M.

2011 Pinning Down the Past: Archaeology, Heritage, and Education Today. Woodbridge: The Boydell Press.

Członkowski D.

1969a Sprawozdanie z ratowniczych badań wykopaliskowych grodziska nad Radwią, Stare Borne, pow. Koszalin, stanowisko 1, w latach 1967 i 1968. W: F. Lachowicz (red.), Sprawozdania z badań archeologicznych prowadzonych na terenie woj. koszalińskiego Członkowski D. w latach 1967-1968 (s. 130-141). Koszalin: Prezydium Wojewódzkiej Rady Narodowej.

1969b Sprawozdanie z ratowniczych badań na wczesnośredniowiecznym cmentarzysku kurhanowym w Żydowie, pow. Sławno, stanowisko 1 w 1968 r. W: F. Lachowicz (red.), 
Sprawozdania z badań archeologicznych prowadzonych na terenie woj. koszalińskiego Jameson J.H. Jr. (red.)

w latach 1967-1968 (s. 142-145). Koszalin: Prezydium Wojewódzkiej Rady Narodowej.

1997 Presenting Archaeology to the Public: Digging for Truths. Walnut Creek: Altamira Press.

Giaccardi E. (red.)

2012 Heritage and Social Media: Understanding Heritage in a Participatory Culture. London, New York: Routledge.

Jaskanis J.

1999 Ochrona zabytków archeologicznych w Polsce w latach 1964-1990. Uwagi uczestnika zdarzeń. W: Z. Kobyliński, J. Wysocki (red.), Tadeusz Roman Żurowski i konserwatorstwo archeologiczne $w$ Polsce XX wieku (s. 173-188). Warszawa: Stowarzyszenie Naukowe Archeologów Polskich.

Józefowska M.

2002 Chronić czy udostępniać?: głos konserwatorski w sprawie użytkowania obiektów archeologicznych. W: W. Rączkowski, J. Sroka (red.), De rebus futuris memento: przyszłość przeszłego krajobrazu kulturowego Ziemi Sławieńskiej (s. 79-86). Sławno: Fundacja Dziedzictwo.

Kaźmierczak P., Zapłata R.

2015 Wyniki weryfikacyjnych badań powierzchniowych rejonu Bobolic w 2015 roku. W: M. Pawleta, R. Zapłata (red.), Nieinwazyjne rozpoznanie zasobów dziedzictwa archeolo-

Kleist von D. gicznego: potencjat i możliwości (s. 49-73). Lublin: Wydawnictwo E-naukowiec.

1955 Die urgeschichtlichen Funde des Kreises Schlawe. Hamburg: Museum für Völkerkunde.

Kobyliński Z.

2001 Teoretyczne podstawy konserwacji dziedzictwa archeologicznego. Warszawa: Fundacja Res Publica Multiethnica, IAiE PAN.

Kobyliński Z.

2009a Wtasność dziedzictwa archeologicznego: idee - problemy - kontrowersje. Warszawa: Instytut Archeologii i Etnologii PAN.

Kobyliński Z.

2009b Archeologia wobec wyzwań współczesności. W: M. Brzostowicz (red.), Archeologia polska i jej czasy (s. 103-131). Poznań: Wydawnictwo Poznańskiego Towarzystwa Przyjaciół Nauk.

Koźniewski P.

2014 Smartfony i tablety w popularyzacji archeologii. W: S. Ździebłowski (red.), Cyfrowy archeolog. Podręcznik promocji archeologii w nowych mediach (s. 69-86). Poznań: Muzeum Archeologiczne w Poznaniu.

Lytras M., Ordonez De Pablos P., Damiani E., Diaz L. (red.)

2011 Digital Culture and E-Tourism: Technologies, Applications and Management. Hershey: IGI Global.

Łosiński W., Olczak J., Siuchniński K.

1971 Źródta archeologiczne do studiów nad wczesnośredniowiecznym osadnictwem grodowym na terenie województwa koszalińskiego (t. 4). Poznań: Uniwersytet im. Adama Mickiewicza.

Malinowska-Sypek A., Sypek R., Sukniewicz D.

2010 Przewodnik archeologiczny po Polsce. Warszawa: Arkady.

McGimsey C.

1972 Public archaeology. New York, London: Seminar Press. 
Okamura K., Matsuda A. (red.)

2011 New Perspectives in Global Public Archaeology. New York: Springer.

Olczak J., Siuchniński K.

1968 Źródła archeologiczne do studiów nad wczesnośredniowiecznym osadnictwem grodowym na terenie województwa koszalińskiego (t. 2). Poznań: Uniwersytet im. Adama Mickiewicza.

Pawleta M.

2015a Dziedzictwo archeologiczne we współczesnych strategiach popularyzatorskich. W: M. Pawleta, R. Zapłata (red.), Nieinwazyjne rozpoznanie zasobów dziedzictwa archeologicznego: potencjat i możliwości (s. 279-305). Lublin, Poznań: E-Naukowiec.

Pawleta M.

2015b Dziedzictwo archeologiczne rejonu Bobolic. Informator. Poznań, Bobolice. On-line: http://archeo.edu.pl/bobolice/broszura2.pdf, dostęp: 25.10.2016 r.

Pawleta M., Zapłata R. (red.)

2015 Nieinwazyjne rozpoznanie zasobów dziedzictwa archeologicznego: potencjat i możliwości. Lublin: Wydawnictwo E-naukowiec. Online: http://e-naukowiec.eu/nieinwazyjne-rozpozna nie-zasobow-dziedzictwa-archeologicznego-potencjal-i-mozliwosci/, dostęp: 25.10.2016 r.

Piwocki K.

1961 Zabytek, rezerwat, park kultury - muzeum w plenerze. Ochrona Zabytków, 14(3-4), s. $3-4$.

Pluta-Olearnik M.

2010 Zmiany strategii marketingowych w dobie społeczeństwa informacyjnego. Prace Instytutu Lotnictwa, 208, 11-29.

Przyborowska-Klimczak A.

2010 Dziedzictwo kultury. W: K. Zeidler (red.), Leksykon prawa ochrony zabytków. 100 podstawowych pojęć (s. 38-41). Warszawa: Wydawnictwo C.H. Beck.

Purchla J. (red.)

2008 Raport na temat funkcjonowania systemu ochrony dziedzictwa kulturowego w Polsce po roku 1989, Kraków. Online: http://www.kongreskultury.p1/library/File/RaportDziedzictwo/ dziedzictwo_raport_w.pelna(1).pdf, dostęp: 25.10.2016 r.

Rajewski Z.

1968 Rezerwaty archeologiczne i muzea na wolnym powietrzu. Archeologia Polski 13(2), s. $429-441$.

Rajewski Z.

1980 Rezerwaty archeologiczne w Polsce - problem definicji i liczby. Ochrona Zabytków Rączkowski W. 33(4), 292-298.

2002 Archeologia w krajobrazie kulturowym: zagrożenia czy szanse. W: W. Rączkowski, J. Sroka (red.), De rebus futuris memento: przyszłość przeszłego krajobrazu kulturowego Ziemi Sławieńskiej (s. 69-78). Sławno: Fundacja Dziedzictwo.

Schofield J.

2008 Heritage management, theory and practice. W: G. Fairclough, R. Harrison, J.H. Jr. Jameson, J. Schofield (red.), The heritage reader (s. 15-30). London, New York: Routledge.

Stone P., Hui Z. (red.)

2014 Sharing Archaeology: Academe, Practice and the Public. New York: Routledge.

Sullivan S., Mackay R. (red.)

2012 Archaeological Sites: Conservation and Management. Los Angeles: Getty Conservation Institute. 


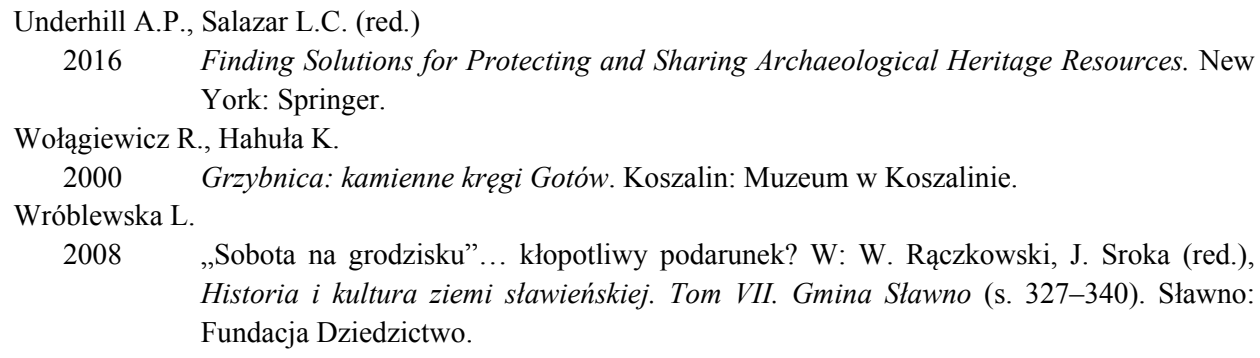

Wrzesiński J.

2008 Archeologia: poznanie - popularyzacja - turystyka. W: H. Machajewski (red.), Wielkopolska $w$ dziejach: archeologia o regionie (s. 173-184). Poznań: Stowarzyszenie Naukowe Archeologów Polskich.

\section{THE DISSEMINATION OF THE ARCHAEOLOGICAL HERIATEG OF THE BOBOLICE REGION: IMPLEMENTATION AND PROPOSITIONS}

\section{Summary}

This paper sets out to present how the research results and knowledge of the archaeological heritage of the Bobolice Region were shared with the general public under the project 'Noninvasive surveying of the potential of archaeological resources in the Bobolice region, West Pomerania Province' and offers further propositions in this regard. The project was implemented between 2014 and 2015 at the Institute of Prehistory, Adam Mickiewicz University, Poznan by an interdisciplinary team consisting of scholars from various centres in Poland: Adam Mickiewicz University, Poznań, Cardinal Stefan Wyszynski University, Warsaw, Warsaw University of Technology, the University of Warsaw, the Museum in Koszalin and the Jan Dekert Lubuskie Museum in Gorzów Wielkopolski. Basically, the project's aim was to conduct research based on the comprehensive use of new non-invasive techniques in archaeology (air laser scanning, satellite images, aerial photographs, geophysical prospection), complemented by verification surface surveys, in order to identify, verify and prepare an inventory of archaeological sites in the Bobolice Region. One of the project's essential objectives was to determine how we can use information generated through non-invasive research methods for the dissemination and popularisation of the archaeological heritage resources to the general public and how to exploit them for the development of tourism in this region of Poland.

This paper provides an overview of the basic principles of the dissemination of knowledge about the cultural and/or archaeological heritage. The issue of the dissemination and popularisation of cultural heritage, including archaeological heritage, is related to the postulate of shaping public awareness of cultural heritage protection. It has been emphasised that the necessity to share and disseminate the knowledge about the archaeological heritage to the general public is not a question of archaeologists' free choice or willingness, but their duty. It stems from the basic premise that archaeological heritage is protected not only for professionals (archaeologists), but for the society. 
It follows that sharing the archaeological heritage with the general public and the popularisation of knowledge in this area constitute one of the most important goals and basics of the conservation and management of archaeological heritage. The protection is thus primarily founded on popularisation and wise education about heritage and its importance. Only by increasing the society's knowledge and awareness about the importance of archaeological heritage and the need to protect it will archaeology be able to involve wider society in the process, for the benefit of both cultural heritage and society.

The paper discusses the key initiatives in the field of sharing research results and the knowledge of archaeological heritage carried out during the project: (1) a seminar 'Non-invasive surveying of archaeological heritage: potential and possibilities', organised at Adam Mickiewicz University, in Poznań; (2) a popular science conference 'Archaeological heritage in the Bobolice and Polanów Regions: survey, potential, prospects', organised in the Centre for Education at the Bobolice Forestry Commission; (3) lessons on the archaeological heritage in the region at the local primary and junior high school in Bobolice, and (4) other promotional activities and publications under the project.

Among others, the project sought to specify the possibilities for a potential use of certain archaeological structures/sites, through actions aimed at their dissemination and making them available to the general public, and a possible use in the development of archaeological tourism in the region. The possibilities for the usage and promotion of certain archaeological structures/sites are many. They include: (1) marking the most spectacular sites, mostly fortified settlements and barrow sites, clearing the area they occupy and setting signboards or information boards; (2) the establishment of archaeological reserves or open-air museums in the case of the most valuable archaeological monuments/sites or their assemblages; (3) preparing detailed information about selected archaeological sites in the region; (4) the use of new technologies, sharing and promoting the archaeological resources of the region (such as social media, QR codes, etc.); (5) using this basis to prepare and educational and recreational offer (cycling paths, walking trails combined with archaeological sites) and thematic routes for different audiences; (6) organisation of outdoor events promoting the knowledge of the past and the region, demonstrations of experimental archaeology, archaeological and historical fêtes, shows and presentations of old crafts; (7) organisation of an exhibition on the archaeological heritage in the region. The proposed exhibition would present the discoveries on educational posters, large-format photographs and posters showing the artefacts and copies thereof; (8) organisation of talks, presentations, as well as popular science lectures addressed to different audiences.

The recommendations presented here should be seen merely as suggestions for potential activities centred on the archaeological heritage resources in the Bobolice region. 